\title{
PENINGKATAN PRESTASI BELAJAR KOMPOSISI FOTO DAN VIDEO DENGAN METODE TUTOR SEBAYA DAN BERBANTUAN MEDIA YOUTUBE
}

\author{
ABDUL ROKHIM \\ Guru SMK Negeri 1 Bangil Kabupaten Pasuruan \\ Email : abdulrokhim675@gmail.com
}

\begin{abstract}
ABSTRAK
Tujuan dari penelitian ini adalah untuk meningkatkan Prestasi Belajar Komposisi Foto dan Video (Type of Shot) siswa kelas XI Produksi dan Siaran Program Televisi (PSPT) SMK Negeri 1 Bangil, metode pembelajaran tutor sebaya (peer tutoring) dan berbantuan youtube sebagai media pembelajaran dengan subyek siswa berjumlah 32 siswa. Penelitian ini merupakan penelitian tindakan kelas yang dilakukan dalam dua siklus dengan tahapan (1) rancangan awal, (2) Pengamatan, (3) Refleksi, dan (4) rancangan yang direvisi. Berdasarkan penelitian yang telah dilakukan, dapat disimpulkan bahwa terdapat peningkatan prestasi belajar Komoposisi Foto dan Vide (Type of Shot) dengan metode pembelajaran tutor sebaya (peer tutoring) dan berbantuan youtube sebagai media pembelajaran yaitu pada siklus I dengan rata-rata 68,91 dan siswa yang mengalami ketuntasan belajar dengan memperoleh nilai $\geq 70$ sebanyak 22 siswa (68,76 \%). Sedangkan pada siklus II dengan rata-rata 82,97 dan siswa yang tuntas belajar sebanyak 28 siswa $(87,50 \%)$ dengan demikian metode pembelajaran tutor sebaya (peer tutoring) dan berbantuan youtube sebagai media pembelajaran dapat meningkatkan prestasi belajar Komposisi Foto dan Video (Type of Shot) siswa kelas XI Produksi dan Siaran Program Televisi (PSPT) SMK Negeri 1 Bangil dan bisa digunakan di sekolah lainnya pada mata pelajaran yang berbeda
\end{abstract}

Kata Kunci : Youtube, Tutor Sebaya, Komposisi Foto dan Video

\section{PENDAHULUAN}

Dalam proses produksi, kamera adalah alat yang paling utama digunakan oleh cameraman/juru kamera. Beberapa cameraman/juru kamer yang memegang kendali dalam proses produksi video/film yaitu First Cameraman, Second Cameraman dan Second Cameraman. First Cameraman sering disebut sebagai Penata Fotografi (Director of Photography) atau kepala kameramen, bertanggung jawab terhadap pergerakan dan penempatan kamera dan juga pencahayaan dalam suatu adegan. Kecuali dalam unit produksi yang kecil, Penata Fotografi tidak melakukan pengoperasian kamera selama syuting yang sesungguhnya. Second Cameraman sering disebut sebagai asisten kameramen atau operator kamera, bertindak sesuai instruksi dari kameramen utama dan melakukan penyesuaian pada kamera atau mengoperasikan kamera selama syuting. First Assistant Cameraman sering disebut Kepala Asisten pada operator kamera dan bertanggung jawab mengatur fokus kamera (untuk kamera film) sedangkan Second Assistant Cameraman, menjadi asisten operator kamera. 
Berdasarkan permasalahan tersebut, maka peneliti menggunakan metode pembelajaran yang dapat membantu siswa kelas XI Produksi dan Siaran Program Televisi (PSPT) SMK Negeri 1 Bangil Kabupaten Pasuruan untuk dapat meningkatkan prestasi belajar komposisi foto dan video (type of shot), yaitu menggunakan metode tutor sebaya (Peer Tutoring) dan berbantuan youtube sebagai media pembelajaran. Selama ini metode tutor sebaya (peer tutoring) dan berbantuan youtube sebagai media pembelajaran belum pernah digunakan dalam pembelajaran komposisi foto dan video (type of shot) di SMK Negeri 1 Bangil Kabupaten Pasuruan.

Metode mengajar merupakan cara atau teknik yang digunakan guru dalam melakukan interaksi dengan peserta didik pada saat proses pembelajaran berlangsung (Winataputra, 2003 : 4). Metode ceramah saja tidak cukup untuk menyampaikan materi ini Oleh karena itu perlu metode pembelajaran yang lainnya, salah satunya adalah metode pembelajaran tutor sebaya (peer tutoring) bisa menjadi salah solusi permasalahan tersebut. Menurut Makarao (2009), tutor sebaya adalah metode pengajaran yang memberi kesempatan pada siswa untuk mengajarkan dan berbagi ilmu pengetahuan atau ketrampilan pada siswa yang lain

Menurut Djamarah dan Zein (2006), penggunaan metode pembelajaran tutor sebaya (peer tutoring), yaitu (1) adakalanya hasilnya lebih baik bagi beberapa siswa yang mempunyai perasaan takut atau enggan kepada gurunya, (2) bagi tutor pekerjaan tutoring akan dapat memperkuat konsep yang sedang dibahas, (3) bagi tutor merupakan kesempatan untuk melatih diri memegang tanggung jawab dalam mengemban suatu tugas dan melatih kesabaran, dan (4) mempererat hubungan antar siswa sehingga mempertebal perasaan sosial.

Penggunaan metode tutor sebaya (peer tutoring) diharapkan dapat meningkatkan penguasaan siswa terhadap pembelajaran komposisi foto dan video (type of shot) yang ditandai dengan meningkatnya motivasi dan prestasi belajar komposisi foto dan video dibuktikan hasil evaluasi yang semakin meningkat. Tutor sebaya (peer tutoring) adalah siswa yang ditunjuk atau ditugaskan guru untuk membantu temannya yang mengalami kesulitan belajar, karena hubungan antar teman umumnya lebih dekat dibandingkan hubungan guru dengan siswa (Abu Ahmadi dan Widodo Supriyono : 2004).

\section{METODE PENELITIAN}

Proses dan hasil belajar mata pelajaran kamera, pencahayaan dan tata suara pada materi bahasan komposisi foto dan video (type of shot) merupakan bahan bagi peneliti/guru untuk menyusun rencana pelaksanaan pembelajaran (RPP). Dalam menyusun rencana pelaksanaan pembelajaran agar dapat meningkatkan motivasi dan prestasi belajar siswa, perlu adanya pemilihan metode dan model pembelajaran yang cocok. Untuk meningkatkan motivasi dan prestasi belajar siswa agar mendapatkan pembelajaran yang berkualitas perlu adanya penelitian tindakan kelas(PTK).

Menurut Mukhlis (2000: 5) Penelitian Tindakan Kelas (PTK) adalah suatu bentuk kajian yang bersifat sistematis reflektif oleh pelaku tindakan untuk memperbaiki kondisi pembelajaran yang dilakukan. Adapun tujuan utama dari penelitian tindakan kelas adalah untuk meningkatkan pratek pembelajaran secara 
berkesinambungan, sedangkan tujuan penyertaannya adalah menumbuhkan budaya meneliti di kalangan guru.

Sesuai dengan jenis penelitian yang dipilih, yaitu penelitian tindakan, maka penelitian ini menggunakan model penelitian tindakan dari Kemmis dan Taggart dalam Arikunto (2007:97), yaitu berbentuk spiral dari siklus yang satu ke siklus yang berikutnya. Setiap siklus meliputi planning (rencana), action (tindakan), observation (pengamatan), dan reflection (refleksi). Langkah pada siklus berikutnya adalah perncanaan yang sudah direvisi, tindakan, pengamatan, dan refleksi. Sebelum masuk pada siklus 1 dilakukan tindakan pendahuluan yang berupa identifikasi permasalahan. Siklus spiral dari tahap-tahap penelitian tindakan kelas dapat dilihat pada gambar berikut :

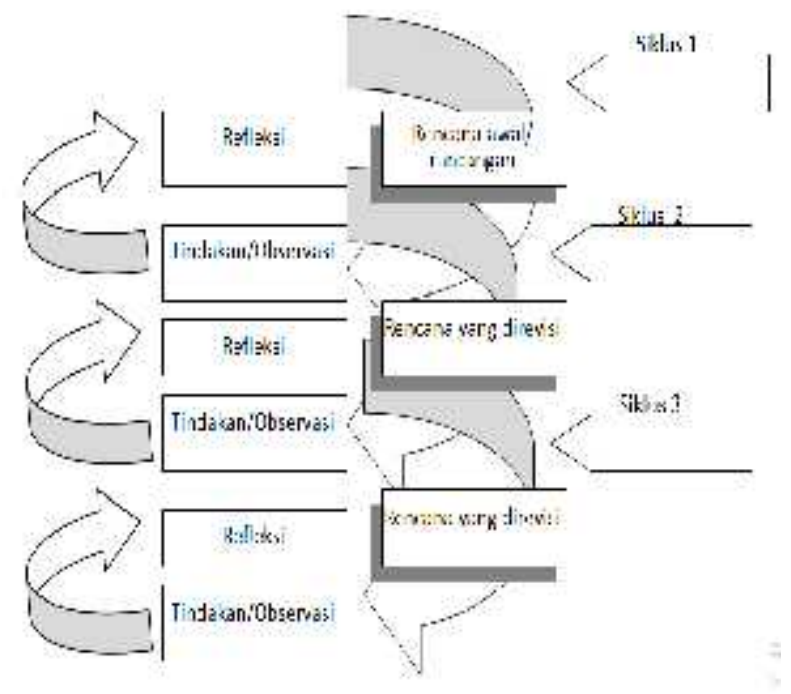

Gambar 1. Alur Penelitian Tindakan Kelas

Penjelasan alur di atas adalah (1) Rancangan/rencana awal, sebelum mengadakan penelitian peneliti menyusun rumusan masalah, tujuan dan membuat rencana tindakan, termasuk di dalamnya instrumen penelitian dan perangkat pembelajaran, (2) kegiatan dan pengamatan, meliputi tindakan yang dilakukan oleh peneliti sebagai upaya membangun pemahaman konsep siswa serta mengamati hasil atau dampak dari diterapkannya metode pembelajaran tutor sebaya, (3) Refleksi, peneliti mengkaji, melihat dan mempertimbangkan hasil atau dampak dari tindakan yang dilakukan berdasarkan lembar pengamatan yang diisi oleh peneliti, dan (4) Rancangan/rencana yang direvisi, berdasarkan hasil refleksi dibuat rancangan revisi untuk pelaksanaan siklus berikutnya.

Pada tahap refleksi dilakukan berdasarkan data yang diperoleh peneliti persiklus, yaitu (1) Jika siklus I sudah memenuhi kriteria ketuntasan kelas yaitu $\geq 80$ $\%$ mencapai nilai $\geq 70$ maka siklus II tidak perlu dilaksanakan dan jika siklus I belum memenuhi kriteria ketuntasan maka perlu diadakan siklus II, (2) Jika siklus II sudah memenuhi kriteria ketuntasan kelas yaitu $\geq 80 \%$ mencapai nilai $\geq 70$ maka siklus III tidak perlu dilaksanakan dan jika siklus II belum memenuhi kriteria ketuntasan maka perlu diadakan siklus III dan seterusnya, dan (3) dalam setiap sklus dikenai perlakuan 
yang sama (alur kegiatan yang sama) dan membahas satu sub pokok bahasan yang diakhiri dengan tes formatif di akhir masing siklus.

Untuk menganalisis tingkat keberhasilan atau presentase keberhasilan siswa setelah proses belajar mengajar setiap siklus dilakukan dengan cara memberikan evaluasi berupa soal tertulis pada setiap akhir siklus.

Analisis kuantitatif ini dihitung dengan menggunakan statistik sederhana yaitu :

1. Menghitung persentase Prestasi Belajar siswa (dayaserap) persiklus dengan menggunakan rumus :

$$
\text { Persentase }(\%)=\frac{\text { Jumlah jawabbenar }}{\text { Nilaimaksimum }} \times 100 \%
$$

2. Menghitung persentase ketuntasan kelas dengan menggunakan rumus :

KetuntasanKelas $=\frac{\text { jumlah siswa yang tuntasbelajar }}{\text { jumlahsiswa }} x 100 \%$

(Purwanto : 2006)

Siswa secara berkelompok atau satu kelas dianggap tuntas belajar bila ketuntasan kelas mencapai $\geq 80 \%$ dari jumlah siswa yang mencapai daya serap $\geq 70$ (kriteriabaik)

\section{HASIL DAN PEMBAHASAN}

Kegiatan survey awal dilakukan sebelum pelaksanaan proses penelitian tindakan kelas berlangsung yang dimaksudkan untuk mengetahui keadaan sebenarnya tentang kondisi pembelajaran komposisi foto dan video (type of shot) SMK Negeri 1 Bangil. Hasil kegiatan tersebut dapat diketahui sebagai berikut: (1) Siswa kelas XI PSPT (Broadcast) SMK Negeri 1 Bangil Kabupaten Pasuruan Tahun Pelajaran 2018/2019 berjumlah 32 siswa. Setelah dilakukan survey awal pembelajaran komposisi foto dan video (type of shot), maka dapat dilihat bahwa pembelajaran kurang berhasil, (2) Perhatian siswa tidak terfokus pada pembelajaran, terutama pada saat guru menyampaikan materi, hal itu disebabkan oleh karena guru belum menggunakan metode pembelajaran yang tepat dalam materi komposisi foto dan video (type of shot), dan (3) Informasi hasil wawancara menunjukkan bahwa siswa kesulitan dan kurang tertarik dalam menerima materi pembelajaran. Hal ini terbukti saat dilakukan pengamatan langsung di lapangan. Siswa terlihat acuh ketika pembelajaran, bahkan ada beberapa siswa yang tetap asik berbicara sendiri dengan teman ketika guru menyampaikan materi. Sebagian siswa merasa takut dan canggung ketika guru memberikan materi, sehingga mereka kurang dapat memahami apa yang disampaikan oleh guru.

Melalui deskripsi data awal, masing-masing aspek menunjukkan bahawa kriteria keberhasilan proses belajar mengajar sangat rendah dan motivasi belajar siswa sangat kurang, maka disusun sebuah tindakan untuk meningkatkan prestasi belajar komposisi foto dan video (type of shot) pada siswa kelas XI PSPT (Broadcast) SMK Negeri 1 Bangil kabupaten Pasuruan tahun pelajaran 2018/2019 dengan menggunakan metode pembelajaran tutor sebaya (perr tutoring).

Menurut Purnomo (2013), langkah-langkah pembelajaran menggunakan metode tutor sebaya adalah sebagai berikut: (1) Tahap Persiapan : Guru membuat program pembelajaran satu pokok bahasan yang dirancang dalam bentuk penggalan- 
penggalan sub pokok bahasan. Setiap penggalan satu pertemuan yang di dalamnya mencakup judul penggalan tujuan pembelajaran, khususnya petunjuk pelaksanaan tugas-tugas yang harus diselesaikan. Menentukan beberapa orang siswa yang memenuhi kriteria sebagai tutor sebaya. Kemudian mengadakan latihan bagi para tutor. Dalam pelaksanaan tutorial, siswa yang menjadi tutor bertindak sebagai guru, (2) Tahap Pelaksanaan : Guru memberikan penjelasan terlebih dahulu tentang materi yang diajarkan, siswa belajar dalam kelompoknya sendiri. Tutor sebaya menanyai anggota kelompoknya secara bergantian akan hal-hal yang belum dimengerti. Jika ada masalah yang tidak terselesaikan barulah tutor meminta bantuan guru, dan guru mengawasi jalannya proses belajar. Guru berpindah-pindah dari satu kelompok ke kelompok lainnya untuk memberikan bantuan jika ada masalah yang tidak dapat diselesaikan dalam kelompok, dan (3) Tahap Evaluasi: Sebelum kegiatan pembelajaran berakhir, guru memberikan soal-soal latihan kepada anggota kelompok (selain tutor) untuk mengetahui apakah sudah menjelaskan dan menjalankan tugasnya, serta mengingatkan siswa untuk mempelajari sub pokok bahasan sebelumnya Pelaksanaan tindakan dilakukan dengan 2 siklus yang masing-masing siklus terdiri dari 3 tahapan, yaitu tahap persiapan, tahap pelaksanaan,dan tahap evaluasi (observasi, dan refleksi).

\section{Siklus I}

Siklus I dilaksanakan selama 5 x 45 menit pada hari Senin, 4 Februari 2019 dan hari Jum'at, 8 Februari 2019. Materi pembelajaran siklus I adalah komposisi foto dan video (type of shot) yang dilaksanakan dengan langkah-langkah sebagai berikut : (1)Peneliti memberikan apersepsi berupa pertanyaan tentang komposisi foto dan video untuk mengetahui sejauh mana penguasaan materi komposisi foto dan video (type of shot) sebelum menggunakan metode tutor sebaya, (2) Peneliti menyampaikan tujuan yang ingin dicapai dalam pembelajaran.
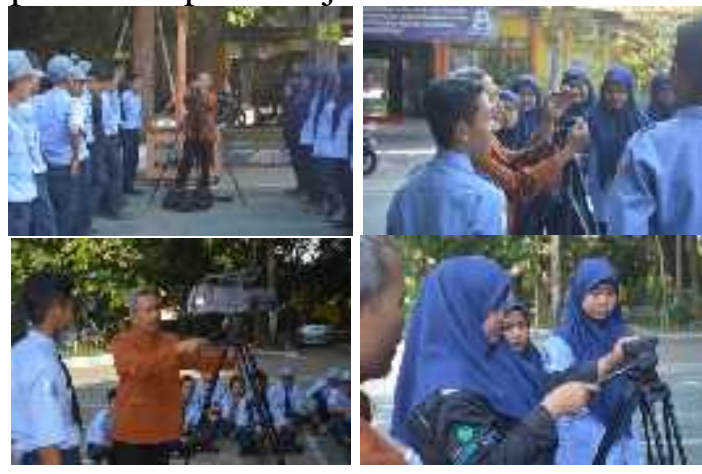

(3) Peneliti membantu peserta didik menyiapkan bahan dan alat yang akan digunakan dalam pembelajaran, (4) Peneliti membuat kelompok-kelompok yaitu 8 anak setiap kelompok, pada tiap kelompok ada 1 anak yang sudah bisa atau pandai dalam materi komposisi foto dan video (type of shot) yang bertugas sebagai tutor teman sebaya. 


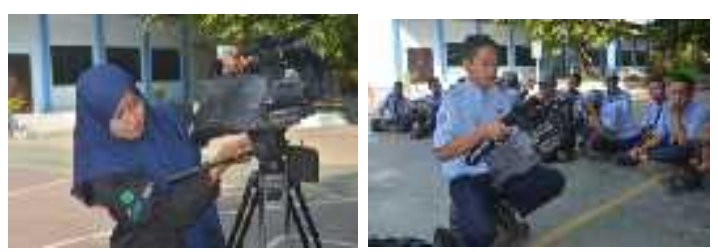

(5) Peneliti memerintahkan tutor sebaya untuk memberikan bimbingan tentang komposisi foto dan video (type of shot) yang benar, (6) Tutor sebaya memberi contoh dan bimbingan tentang komposisi foto dan video (type of shot) yang benar, yaitu dengan beberapa tahapan.
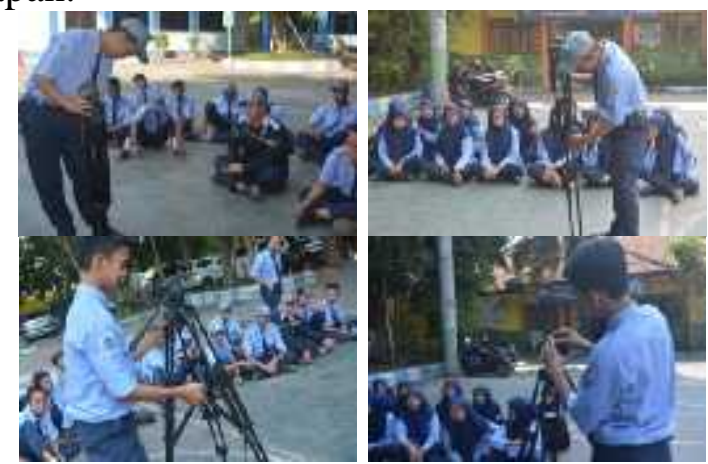

(7) Setelah tutor sebaya selesai, peneliti memberikan penghargaan bagi peserta didik yang melakukan pengambilan gambar dengan memperhatikan komposisi foto dan video (type of shot) dengan benar, dan (8) di akhir pertemuan peneliti menginformasikan bahwa pada pertemuan selanjutnya hari Senin, 11 Februari 2019 diadakan evaluasi tentang komposisi foto dan video (type of shot). Pada pertemuan selanjutnya yaitu Senin, 11 Februari 2019 diadakan penilaian/evaluasi tentang komposisi foto dan video (type of shot), dengan mengerjakan soal evaluasi yang telah disediakan oleh peneliti/guru mata pelajaran. Adapun hasil yang diperoleh dari evaluasi/tes pada pembelajaran siklus I adalah :

\section{Tabel 1. Prestasi belajar Komposisi Foto dan Video pada siklus I}

\begin{tabular}{ccccc}
\hline No & $\begin{array}{c}\text { Nilai Siswa } \\
(\mathrm{x})\end{array}$ & $\begin{array}{c}\text { Jumlah Siswa } \\
(\mathrm{y})\end{array}$ & $(\mathrm{x})(\mathrm{y})$ & Ket. \\
\hline 1 & 50 & 1 & 50 \\
2 & 55 & 2 & 110 \\
3 & 60 & 4 & 240 \\
4 & 65 & 3 & 195 \\
5 & 70 & 10 & 700 \\
6 & 75 & 10 & 750 \\
7 & 80 & 2 & 160 \\
8 & 85 & 0 & 0 \\
9 & 90 & 0 & 0 \\
10 & 95 & 0 & 0 \\
11 & 100 & 0 & 0 \\
\hline \multicolumn{5}{c}{ Jumlah } \\
\hline
\end{tabular}




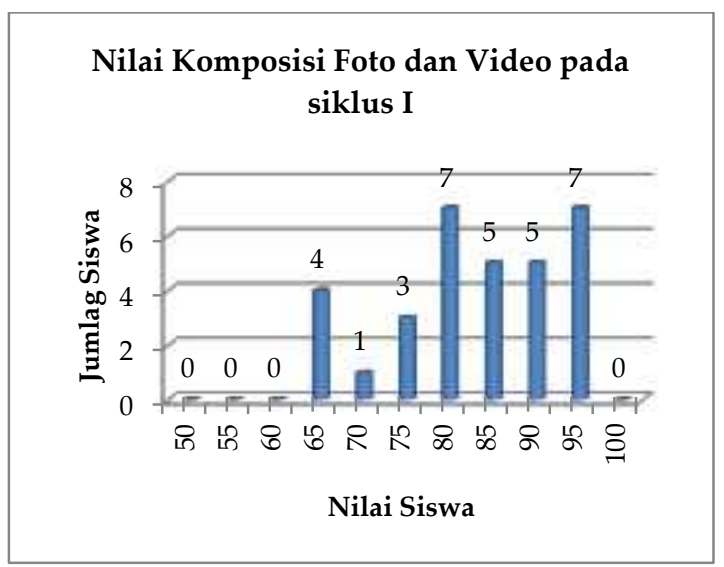

\section{Gambar 2. Grafik Nilai Komposisi Foto dan Video pada Siklus I}

Tabel 2. Ketuntasan belajar Komposisi Foto dan Video pada siklus I

\begin{tabular}{c|c|c|c|c}
\hline No & Ketuntasan Belajar & $\begin{array}{c}\text { Jumlah Siswa } \\
(\mathrm{y})\end{array}$ & $\begin{array}{c}\text { Prosentase } \\
\text { Ketuntasan }\end{array}$ & $\begin{array}{c}\text { Ket } \\
\text {. }\end{array}$ \\
\hline 1 & Belum Tuntas & 10 & $31,25 \%$ & \\
2 & Tuntas & 22 & $68,75 \%$ & \\
\hline
\end{tabular}

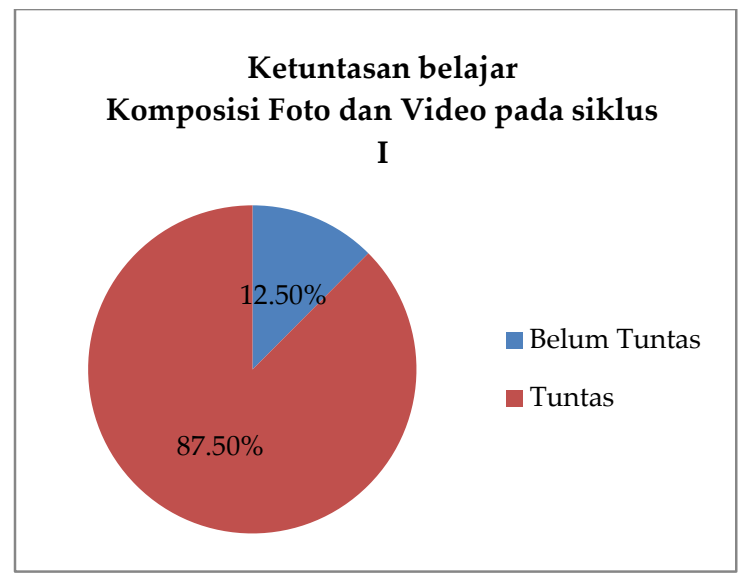

\section{Gambar 3. Nilai Ketuntasan Belajar Komposisi Foto dan Video pada Siklus I}

Dalam melaksanakan tindakan siklus I terdapat kelebihan yang dapat digunakan sebagai tolok ukur keberhasilan pelaksanaan tindakan siklus I, yaitu (1) Siswa merasa tertarik dengan penyampaian materi yang menggunakan metode pembelajaran tutor sebaya sebab siswa tidak merasa takut atau canggung dengan tutor sebaya yang merupakan teman sendiri, (2) Siswa mudah menyerap materi yang disampaikan oleh tutor sebaya, sehingga pembelajaran berjalan efektif, dan (3) Siswa dapat beradaptasi secara cepat dengan pembelajaran yang dibantu oleh tutor sebaya. Sedangkan kelemahan, yaitu (1) Masih banyak siswa yang belum dapat melakukan pengambilan gambar berupa foto maupun video dengan benar, (2) Banyak siswa yang masih takut melakukan kesalahan, sehingga ragu-ragu dalam melakukan pengambilan 
gambar berupa foto maupun video, dan (3) Masih ada siswa yang bercanda dengan tutor sebaya karena mereka adalah teman, sehingga pembelajaran terganggu.

Berdasarkan hasil pengamatan terhadap proses pembelajaran komposisi foto dan video (type of shot) pada siklus I diperoleh gambaran tentang motivasi dan prestasi belajar siswa, yaitu nilai rata-rata kelas 68,91 dan dari 32 siswa terdapat 22 siswa $(68,75 \%)$ telah mencapai kriteria ketuntasan $\geq 70$ dan sisanya 10 siswa $(31,25$ $\%)$ belum mencapai kriteria ketuntasan $<70$. Karena prestasi belajar siswa siklus I belum maksimal meskipun telah menunjukkan peningkatan, akan tetapi belum sesuai dengan target pencapaian yaitu kurang dari $80 \%$ siswa yang mencapai target, maka perlu diadakan pembelajaran siklus II.

\section{Siklus II}

Siklus II dilaksanakan selama 5 x 45 menit pada hari Senin, 18 Februari 2019 dan hari Jum'at, 22 Februari 2019. Materi pembelajaran siklus II adalah komposisi foto dan video (type of shot) yang dilaksanakan dengan langkah-langkah sebagai berikut: (1) Peneliti memberikan apersepsi berupa pertanyaan tentang komposisi foto dan video untuk mengetahui sejauh mana penguasaan materi komposisi foto dan video (type of shot) sebelum menggunakan metode tutor sebaya, (2) Peneliti menyampaikan tujuan yang ingin dicapai dalam pembelajaran, (3) Peneliti membantu peserta didik menyiapkan bahan dan alat yang akan digunakan dalam pembelajaran, (4) Peneliti membuat kelompok yaitu 8 anak setiap kelompok, pada tiap kelompok ada 1 anak yang sudah bisa atau pandai dalam materi komposisi foto dan video (type of shot) yang bertugas sebagai tutor teman sebaya, (5) Peneliti memerintahkan tutor sebaya untuk memberikan bimbingan tentang komposisi foto dan video dengan benar, (6) Tutor sebaya memberi contoh dan bimbingan tentang komposisi foto dan video (type of shot) yang benar, yaitu dengan beberapa tahapan, (7) Setelah tutor sebaya selesai, peneliti memberikan penghargaan bagi peserta didik yang melakukan pengambilan gambar dengan memperhatikan komposisi foto dan video dengan benar, dan (8) di akhir pertemuan peneliti menginformasikan bahwa pada pertemuan selanjutnya hari Senin, 25 Februari 2019 diadakan evaluasi tentang komposisi foto dan video (type of shot).

Pada pertemuan selanjutnya yaitu Senin, 25 Februari 2019 diadakan penilaian/evaluasi tentang komposisi foto dan video (type of shot), dengan mengerjakan soal evaluasi yang telah disediakan oleh peneliti/guru mata pelajaran. Penilaian dilakukan secara individu untuk mengetahui keberhasilan dan keefektifan penggunaan metode pembelajaran tutor sebaya (peer tutoring). Adapun hasil yang diperoleh dari evaluasi/tes pada pembelajaran siklus I adalah : 
Tabel 3: Prestasi belajar Komposisi Foto dan Video pada siklus I

\begin{tabular}{ccccc}
\hline No & $\begin{array}{c}\text { Nilai Siswa } \\
(\mathrm{x})\end{array}$ & $\begin{array}{c}\text { Jumlah Siswa } \\
(\mathrm{y})\end{array}$ & $(\mathrm{x})(\mathrm{y})$ & Ket. \\
\hline 1 & 50 & 0 & 0 \\
2 & 55 & 0 & 0 \\
3 & 60 & 0 & 0 \\
4 & 65 & 4 & 260 \\
5 & 70 & 1 & 70 \\
6 & 75 & 3 & 225 \\
7 & 80 & 7 & 560 \\
8 & 85 & 5 & 425 \\
9 & 90 & 5 & 450 \\
10 & 95 & 7 & 665 \\
11 & 100 & 0 & 0 \\
\hline Jumlah & \multicolumn{5}{c}{2655} \\
\hline Rata-rata & \multicolumn{5}{c}{82,97} \\
\hline
\end{tabular}

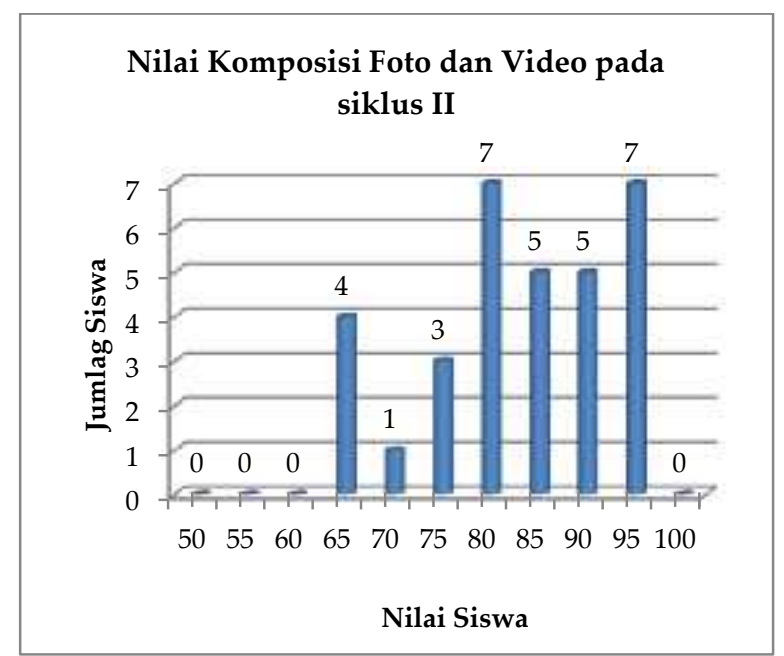

Gambar 4. Grafik Nilai Komposisi Foto dan Video pada Siklus II

Tabel 4. Ketuntasan belajar Komposisi Foto dan Video pada siklus II

\begin{tabular}{c|c|c|c|c}
\hline No & Ketuntasan Belajar & $\begin{array}{c}\text { Jumlah Siswa } \\
(\mathrm{y})\end{array}$ & $\begin{array}{c}\text { Prosentase } \\
\text { Ketuntasan }\end{array}$ & $\begin{array}{c}\text { Ket } \\
\text {. }\end{array}$ \\
\hline 1 & Belum Tuntas & 4 & $12,50 \%$ & \\
2 & Tuntas & 28 & $87,50 \%$ & \\
\hline
\end{tabular}




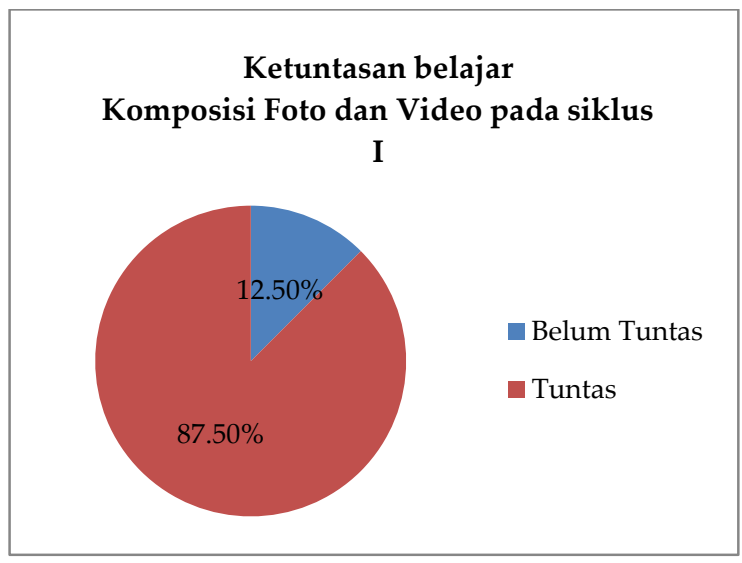

\section{Gambar 5. Nilai Ketuntasan Belajar Komposisi Foto dan Video pada Siklus II}

Dalam melaksanakan tindakan siklus II terdapat kelebihan yang dapat digunakan sebagai tolok ukur keberhasilan pelaksanaan tindakan adalah (1) Siswa merasa tertarik dengan penyampaian materi yang menggunakan metode pembelajaran tutor sebaya sebab siswa tidak merasa takut atau canggung dengan tutor sebaya yang merupakan teman sendiri, (2) Siswa mudah menyerap materi yang disampaikan oleh tutor sebaya, sehingga pembelajaran berjalan efektif, dan (3) Siswa dapat beradaptasi secara cepat dengan pembelajaran yang dibantu oleh tutor sebaya. Sedangkan kelemahan, yaitu (1) Tinggal sedikit siswa yang belum dapat melakukan pengambilan gambar berupa foto maupun video dengan benar, (2) Tinggal sedikit siswa yang masih takut melakukan kesalahan, sehingga ragu-ragu dalam melakukan pengambilan gambar berupa foto maupun video, dan (3) Sudah tidak ada siswa yang bercanda dengan tutor sebaya meskipun mereka adalah teman sendiri, sehingga pembelajaran berlangsung lancar.

Berdasarkan hasil pengamatan terhadap proses pembelajaran diperoleh gambaran tentang prestasi belajar siswa, yaitu nilai rata-rata 82,97 dan dari 32 siswa terdapat 28 siswa $(87,50 \%)$ telah mencapai kriteria ketuntasan $\geq 70$ dan sisanya 4 siswa $(12,50 \%)$ belum mencapai kriteria ketuntasan < 70. Prestasi belajar siswa siklus II sudah maksimal dan semakin menunjukkan peningkatan, sehingga sesuai dengan target pencapaian yaitu lebih dari $80 \%$ siswa yang mencapai target, maka tidak perlu diadakan pembelajaran siklus III.

\section{Prestasi Belajar}

Belajar adalah proses mencari jawaban dari yang tidak tahu menjadi tahu. Menurut Reg Revans (1998), belajar adalah proses menanyakan sesuatu yang berawal dari ketidaktahuan tentang apa yang dilakukan. Di dalam Kamus Besar Bahasa Indonesia menyebutkan belajar adalah berusaha memperoleh kepandaian atau ilmu (1993:13). Sedangkan belajar menurut Suharsimi Arikunto (1993:19) adalah suatu proses yang terjadi karena adanya usaha untuk mengadakan perubahan terhadap diri manusia yang melakukan, dengan maksud memperoleh perubahan dalam dirinya, baik berupa pengetahuan, keterampilan, ataupun sikap. 
Dari beberapa pendapat di atas dapat disimpulkan bahwa belajar merupakan suatu perubahan tingkah laku dalam berbagai aspek kepribadian, (yang idealnya) perubahan tersebut merupakan perubahan positif, diperoleh karena yang bersangkutan menghendaki perubahan, dan perubahan itu dicapai melalui tahapan latihan dan atau pengalaman.Menurut Mulyono Abdurrahman (2003:37) "Prestasi belajar adalah kemampuan yang diperoleh anak setelah melalui kegiatan belajar". Dalam kegiatan pembelajaran tujuan yang ingin dicapai ditentukan sebelumnya. Anak yang dikatakan berhasil adalah mereka yang dapat mencapai tujuan-tujuan pelajaran yang telah ditentukan sebelumnya.

Dimyati dan Mujiono (2006:3) memaparkan bahwa "Prestasi belajar merupakan hasil dari suatu interaksi tindak belajar dan tindak mengajar". Prestasi belajar merupakan pencapaian tujuan pengajaran dan kemampuan mental siswa. Setelah selesai mempelajari materi, diadakan evaluasi belajar untuk mengetahui tingkat pencapaian tujuan pembelajaran yang telah ditentukan sebelumnya, sebelum dilanjutkan pada jenjang yang lebih tinggi. Hal senada juga disampaikan oleh Nana Sudjana (2006) bahwa prestasi belajar adalah kemampuan-kemampuan yang dimiliki siswa atau mahasiswa setelah ia menerima pengalaman belajarnya.

Berdasarkan teori di atas dapat disimpulkan bahwa prestasi belajar adalah kemampuan yang diperoleh anak setelah melalui kegiatan belajar. Prestasi belajar merupakan penguasaan berbagai macam keterampilan, pengetahuan setelah siswa memperoleh pengalaman belajar. Dalam kegiatan pembelajaran tujuan yang ingin dicapai ditentukan sebelumnya. Anak yang dikatakan berhasil adalah mereka yang dapat mencapai tujuan-tujuan pembelajaran yang telah ditentukan sebelumnya.

Prestasi belajar siswa dipengaruhi oleh dua faktor utama yakni faktor dari dalam diri siswa dan faktor yang datang dari luar siswa, yaitu (a) Faktor dari dalam diri siswa , dimana prestasi belajar siswa di sekolah $70 \%$ dipengaruhi oleh siswa dan $30 \%$ dipengaruhi oleh lingkungan (Rusna Ristasa, 2003). Berkaitan dengan faktor diri siswa yaitu motivasi, minat, sikap perhatian, kebiasaan belajar, ketekunan, kondisi sosial ekonomi, dan kondisi fisik dan psikis. Dan (b) Faktor dari luar siswa yang dominan mempengaruhi prestasi belajar adalah kualitas pengajaran. Yang dimaksud kualitas pengajaran adalah tinggi/ rendahnya atau efektif/tidaknya proses pembelajaran dalam mencapai tujuan. Metode pembelajaran juga sangat berpengaruh dalam pencapaian prestasi belajar. Pemilihan metode yang tepat mutlak diperlukan agar pembelajaran menjadi menyenangkan dan berkesan bagi siswa yang akhirnya dapat meningkatkan prestasi belajar siswa.

\section{Komposisi Foto dan Video (type of shot)}

Pada kesempatan kali ini peneliti akan membagikan informasi tentang komposisi dalam pengambilan fotografi maupun videografi, agar gambar yang dihasilkan tidak monoton yang sering digunakan dalam industri perfilman. Komposisi foto dan video mengacu pada segala sesuatu dalam sebuah bingkai atau frame, seperti subyeknya apa, letaknya dimana, latar belakangnya apa, latar depannya apa, pencahayaan, dan lain sebagainya.

Yang harus diperhatikan dalam Komposisi Foto dan Video (type of shot) antara lain (1) The Rule of Thirds yaitu (a) aturan ini membagi frame menjadi 3 
bagian, (b) penekanannya yaitu 1/3 atau 2/3 frame, daripada ditengah frame, (c) pada saat membidik dengan mode mendatar atau landscape, ambil bagian dataran atau bawah kurang lebih 1/3 frame, kemudian sisanya untuk mengambil bagian atas atau langit, (d) pada kebanyakan orang, penekanan dalam mengambil video adalah lurus dengan titik pusat subyeknya, (e) titik pusat itu bisa terletak pada 1/3 dari bagian framenya, (f) hindari meletakkan bagian utama pada titik tengah dari frame, karena gambar yang dihasilkan terlalu simetris dan tidak menarik perhatian mata untuk melihatnya, dan (g) buat gambar yang tidak simetris, karena dengan itu akan menimbulkan efek kegembiraan, ketegangan, dan juga gerakan gambar. Dan (2) Headroom, Leading/Walking Room dan Looking/Nose Room, yaitu (a) Terminologi ini mengacu pada banyaknya ruang yang ada dalam sebuah frame yang dibiarkan kosong, (b) Anda perlu membuat sebuah ruang kosong didepan muka dari obyek anda, (c) Ruang kosong ini dinamakan dengan "talking room". Jika seseorang sedang berbicara dengan orang lain, maka "talking room" ini memberikan efek natural pada gambar, (d) Walking room, jika seseorang sedang berjalan, maka berikan juga ruang kosong untuk berjalan ini, (e) Sedangkan Head room adalah ruang kosong antara batas atas dari obyek dengan batas atas dari frame, (f) Kesalahan yang sering dilakukan adalah memberikan head room terlalu lebar, sehingga menghabiskan ruangan frame terlalu banyak, (g) Hindari mengambil setengah gambar dalam sebuah frame, khususnya obyek manusia (seperti separuh wajah manusia) karena akan sangat tidak enak untuk dilihat, (h) Juga hindari memotong obyek pada sambungansambungannya atau sendi, sebagai contoh anda bisa memotong obyek manusia pada bagian perut, namun jangan memotong pada bagian lututnya, karena itu jelek sekali dan tidak dibenarkan dalam dunia videografi, dan (i) Golden Mean biasa di gunakan untuk format wawancara. Mengapa posisi mata harus terletak 1/3 dari kotak ? agar konsentrasi penonton terfokus pada obyek utama.

\section{Tipe Shot dalam Pengambilan Foto maupun Video}

Dalam produksi foto maupun video, ada sekitar 14 tipe shot dalam pengambilan gambar yang biasa digunakan sebagai acuan para tim produksi (khususnya departemen kamera), masing-masing tipe shot tersebut memiliki fungsi berbeda, hal ini disesuaikan dengan isi pesan yang ingin disampaikan melalui bahasa visual. Terminologi tipe shot (Shot size / type of shot atau ukuran shot), sampai saat ini memang sangat bervariasi di lingkungan produksi audio visual, meski demikian tetap ada prinsip-prinsip dasar yang sama dalam implementasinya.Pemberian nama dan pedoman untuk beragam tipe shot tersebut sampai saat ini seolah telah menjadi kesepakatan umum di industri video, film dan televisi.

Macam-macam Tipe Shots dalam pengambilan gambar yang sering digunakan dalam produksi film dan video diantaranya : (1) EWS (Extreme Wide Shot): merupakan tipe shot yang digunakan untuk menunjukkan sebuah lingkungan dimana subyek film berada. Tipe shot ini seringkali dipakai untuk membangun suasana sebuah adegan, subyek film terkadang hampir tak tampak dalam visual karena penggunaan sudut pandang lebar yang ekstrim,, (2) Very Wide Shot (VWS) : merupakan tipe shot sangat luas, namun secara visual lebih sempit jika dibandingkan 
dengan tipe Extreme wide shot. Pengambilan gambar dengan tipe Very Wide Shot ini masih sangat memungkinkan untuk mengambil banyak subyek dalam sebuah frame. (3) Wide Shot (WS): subjek sudah dapat diidentifikasikan dengan jelas karena telah memenuhi frame gambar meski terdapat jarak diatas kepala dan dibawah kaki. Penggunaan jarak diatas dan dibawah subyek tersebut digunakan untuk ruang aman agar lebih nyaman untuk dilihat, (4) Mid Shot (MS): sering disebut juga sebagai Medium Shot merupakan shot yang menunjukkan beberapa bagian dari subjek secara lebih rinci, pada subyek manusia tipe shot ini akan menampilkan sebatas pinggang sampai atas kepala, (5) Medium Close Up (MCU): merupakan jenis shot untuk menunjukkan wajah subyek agar lebih jelas dengan ukuran shot sebatas dada hingga kepala. Ekpresi wajah dari tipe shot ini sudah bisa ditangkap melalui frame kamera. (6) Close $U p$ ( $C U$ : sering digunakan untuk menekankan keadaan emosional subyek. Tipe shot ini biasanya mengambil subyek manusia hanya bagian kepala saja, (7) Extreme Close $U p(E C U, X C U)$ : merupakan tipe shot untuk menampilkan detail obyek, misalnya mata, hidung, atau telinga, (8) Cut-In (CI): adalah tipe shot yang diambil secara khusus dengan menunjukkan beberapa bagian dari subjek secara rinci, biasanya digunakan untuk menekankan emosi subyek, misalnya gerakan tangan, gerakan kaki, atau yang lainnya sehingga bisa menunjukkan antusiasme, agitasi, kegelisahan, atau apapun yang dialami subyek, (9) Cutaway (CA): adalah jenis shot yang digunakan untuk membangun situasi, subjek bisa berbeda, misalnya hewan kesayangan milik subyek, bagian yang berbeda dari subjek misalnya properti milik subyek, atau apa pun, (10) Two Shot: merupakan tipe shot yang menampilkan dua orang dalam satu frame kamera, tipe shot ini dapat digunakan untuk membangun hubungan antara subjek satu dengan lainnya, (11) Over the Shoulder Shot (OSS): merupakan tipe shot yang dilakuakan untuk dua subyek, namun pengambilan gambar dilakuakan dari belakang bahu salah satu subyek, (12) Noddy Shot : biasanya digunakan dalam wawancara maupun dialog. Tipe shot ini juga digunakan untuk menangkap respons maupun reaksi salah satu subyek saat subyek lain bicara dalam pengambilan gambar Over the Shoulder shot, (13) Point-of-View Shot (POV): adalah tipe shot yang menunjukkan sesuatu dari sudut pandang subjek, dalam hal ini fungsi kamera sebagai mata subjek, dan (14) Weather Shot : merupakan tipe shot yang menjelaskan tentang cuaca dimana subyek berada. Shot-shot cuaca biasanya juga dapat digunakan untuk mewakili suasana hati subyek.

\section{Tutor Sebaya}

Tutor sebaya (peer tutoring) adalah seorang siswa yang ditunjuk atau ditugaskan guru untuk membantu temannya yang mengalami kesulitan belajar, karena hubungan teman umumnya lebih dekat dibandingkan hubungan guru dengan siswa (Abu Ahmadi dan Widodo Supriyono, 2004). Dedi Supriyadi mengemukakan, bahwa tutor sebaya adalah seorang atau beberapa orang siswa yang ditunjuk dan ditugaskan untuk membantu siswa yang mengalami kesulitan belajar.

Menurut Arjanggi dan Suptihatin (2010), tutor sebaya adalah suatu metode pembelajaran yang dilakukan dengan cara memberdayakan siswa yang memiliki daya serap tinggi dari kelompok siswa itu sendiri untuk menjadi tutor bagi teman- 
temannya, dimana siswa yang menjadi tutor bertugas untuk memberikan materi belajar dan latihan kepada teman-temannya (tutee) yang belum paham terhadap materi atau latihan yang diberikan guru dengan dilandasi aturan yang telah disepakati bersama dalam kelompok tersebut, sehingga akan terbangun suasana belajar kelompok yang bersifat kooperatif bukan kompetitif.

Menurut Ischak (1987), tutor sebaya adalah teman sekelas yang telah tuntas terhadap bahan, yang memberikan bantuan pada siswa yang menemui kesulitan dalam memahami bahan yang dipelajari, tutor sebaya ini diharapkan siswa tidak malu dan takut bertanya pada temannya sendiri tentang bahan ajar yang belum dipahami. Hal yang senada juga disampaikan oleh Winataputra (1999), tutor sebaya adalah kegiatan belajar siswa dengan memanfaatkan teman sekelas yang mempunyai kemampuan lebih untuk membantu temannya dalam melaksanakan suatu kegiatan atau memahami suatu konsep.

Adapun menurut Satriyaningsih (2008), kriteria tutor sebaya adalah sebagai berikut: (1) memiliki kemampuan akademis di atas rata-rata siswa satu kelas, (2) memiliki kecakapan dalam menerima pelajaran yang disampaikan oleh guru, (3) mampu menjalin kerja sama dengan sesama siswa, (4) memiliki motivasi tinggi untuk menjadikan kelompok tutornya sebagai yang terbaik, (5) dapat diterima dan disenangi siswa yang mendapat program pembelajaran tutor sebaya, sehingga siswa tidak mempunyai rasa takut atau enggan untuk bertanya kepada guru dan rajin, (6) tidak tinggi hati, kejam atau keras hati terhadap sesama kawan, dan (7) mempunyai daya kreatifitas yang cukup untuk memberikan bimbingan yaitu dapat menerangkan pelajaran dengan teman sebayanya

Berdasarkan teori-teori di atas, maka dapat disimpulkan bahwa tutor sebaya adalah bagaimana mengoptimalkan kemampuan siswa yang berprestasi dalam satu kelas untuk mengajarkan atau menularkan kepada teman sebaya mereka yang kurang berprestasi. Sehingga siswa yang kurang berprestasi bisa mengatasi ketertinggalan. Pembimbingan dalam pelajaran yang diberikan oleh seorang siswa kepada siswa lain, sedangkan mereka (antara pembimbing dan yang dibimbing) adalah teman sekelas atau teman sebangku yang usianya relatif sama, dan siswa yang kurang paham bisa bertanya langsung kepada teman sebangkunya (tutor yang di tunjuk) sehingga kondisi kelas pun bisa hidup karena siswa tidak malu bertanya ketika mereka tidak paham.

\section{Youtube sebagai Video Pembelajaran}

Youtube adalah situs berbagai video yang sangat populer hingga saat ini. "Sekitar 100.000 video ditonton setiap harinya di Youtube. Setiap 24 jam ada 65.000 video baru diunggah ke Youtube. Setiap bulannya Youtube dikunjungi oleh 20 juta penonton dengan mayoritas kisaran usia antara 12 tahun sampai 17 tahun" (Burke, Snyder,\& Rager, 2009). Youtube memang bukan situs berbagi video pendidikan, namun pada perkembangannya Youtube meluncurkan layanan khusus untuk pendidikan (www.youtube.com/edu) pada tahun 2009.

Keuntungan pembelajaran dengan video adalah menghadirkan representasi gambar dan suara dari sebuah gagasan atau peristiwa kepada pembelajar di kelas. berbagi video di internet yang paling populer saat ini. Youtube sebagai sumber belajar by utilization dengan hasil belajar, dan untuk mengetahui ada atau tidaknya 
pengaruh motivasi belajar dalam penggunaan Youtube sebagai sumber belajar by utilization terhadap hasil belajar mahasiswa (Hamim Tohari, 2019)

Media pembelajaran yang berbentuk video yang begitu menarik merupakan salah satu strategi penyampaian pesan kepada siswa dari konten yang relatif berat. Rivalina (2017) mengatakan bahwa siswa kurang memberikan respon positif pada kegiatan pembelajaran jika konten yang kurang menarik. Strategi penyampaian konten dengan media yang tepat terbukti mampu meningkatkan prestasi belajar (Prastiyo, Djohar, \& Purnawan, 2018. Media video presentasi dinilai cukup berhasil membuat kontek komposisi foto dan video lebih menarik. Hal ini dikarenakan pesan yang diterima dibuat menjadi lebih ringan dan tidak melelahkan (Carpenter \& Toftness, 2007; Pallett et al, 2018).

Media yang sedianya dapat langsung dimanfaatkan secepatnya justru terkendala dengan teknis dan membutuhkan waktu yang tidak sebentar, berbeda dengan media video presentasi yang ditanam kedalam $e$-learning maupun digunakan langsung dari komputer. Konten yang bersifat natural alamiah cenderung lebih membutuhkan visual, gerak dan suara yang mendekati kenyataan jika digunakan dalam bentuk media pembelajaran (Furi \& Mustaji, 2017.

Hal senada dengan hasil dari ahli media yang menekankan tentang indikator proporsi gambar, harmonisasi huruf, warna dan penjelasan narator. Selain itu juga ditambahkan bahwa kekuatan media yang sesuai dengan tujuan dan materi pembelajaran (Smaldino, Lowthe \& Russell, 2012). Kepraktisan, serta karakteristik siswa merupakan kunci keberhasilan sebuah media (Rusman, 2016). Terlebih jika ditinjau dari mareti pembelajaran vokasional yang banyak membutuhkan simulasi (Jossberger, Brand-Gruwel, van de wiel, \& Boshuizen, 2017), gambaran riil namun juga harus tetap menarik (Thoma \& Ostendorf, 2017). Semua hal tersebut terkonfirmasi oleh Prastiyo, Djohar dan Purnama (2018) yang mengembangkan serta menggunakan media pembelajaran berbasis daring pada pembelajaran vokasi, teknik mesin. Penggunaan media pembelajaran yang tepat pada mata kulia Hidrologi, khususnya media video presentasi hendaknya benar-benar sesuai dengan karakter mahasiswa sehingga dapat efektif dalam meningkatkan kemampuan mahasiswa dan mengembangkan media pembelajaran, hendaknya perlu memperkaya keilmuannya dengan ilmu tentang pewarnaan, komunikasi dan juga animasi (Aris Maulana, 2019).

Efektivitas media begitu baik bukan hanya karena adanya video yang realistis namun juga tidak membosankan, tapi juga adanya interaksi, kemudahan, kepraktisan dan juga kekinian. Artinya nyaris seluruh aspek yang menjadi fokus para peneliti pengembang media pembelajaran telah terakomodir dalam penelitian ini, sehingga menjadi sebuah kewajaran jika hasilnya yang cukup baik. Selanjutnya, hasil studi Lestari (2015) menyimpulkan bahwa belum semua guru memanfaatkan TIK dalam menyelenggarakan kegiatan pembelajaran walaupun telah memahami TIK sangat menunjang atau meningkatkan penguasaan materi pelajaran peserta didik. Hasil penelitian terhadap penerapan model discovery menunjukkan bahwa pembelajaran discovery learning berbantuan e-learning dapat meningkatkan penguasaan konsep siswa secara signifikan (Zainul Mustafa, 2019). Demikian pula, penelitian terhadap penerapan model blended learning menunjukkan bahwa penerapan model ini efektif untuk meningkatkan kemampuan berpikir kritis dan hasil belajar mahasiswa (Utomo, 
2019). Demikian pula, penelitian terhadap penerapan model blended learning menunjukkan bahwa penerapan model ini efektif untuk meningkatkan kemampuan berpikir kritis dan hasil belajar mahasiswa (Utomo, 2019). Hasil uji Regresi Linier menunjukkan adanya pengaruh yang signifikan antara penggunaan Youtube terhadap motivasi belajar dengan hasil belajar mahasiswa (Hamim Tohari, 2019).

\section{KESIMPULAN}

Berdasarkan analisis data komposisi foto dan video (type shot) siswa kelas XI PSPT (Broadcast) SMK Negeri 1 Bangil kabupaten Pasuruan tahun pelajaran 2018/2019 dapat diperoleh hasil sebagai berikut (1) pada akhir siklus I dari 32 siswa, terdapat 22 siswa $(68,75 \%)$ yang tuntas belajar dan (2) pada akhir siklus II dari 32 siswa, terdapat 28 siswa $(87,50 \%)$ yang tuntas belajar. Dengan demikian penerapan metode pembelajaran tutor sebaya dapat meningkatkan prestasi belajar komposisi foto dan video (type shot) pada siswa kelas XI PSPT (Broadcast) SMK Negeri 1 Bangil kabupaten Pasuruan Tahun Pelajaran 2018/2019.

\section{DAFTAR PUSTAKA}

Abdurrahman, M. 2003. Pendidikan Bagi Anak Berkesulitan Belajar. Jakarta : Rineka Cipta

Ahmadi, A., dan Supriyono, W. 2004. Psikologi Belajar. Jakarta: Rineka Cipta.

Arjanggi, R dan Suprihatin, T. 2010. Metode Pembelajaran Tutor Sebaya Meningkatkan Hasil Belajar Berdasar Regulasi Diri. Makara Sosial Humaniora

Arikunto, S. 2007. Penelitian Tindakan Kelas. Jakarta: Bumi Aksara

Burke, S.C., Snyder, S., Rager, R.C. 2009. An Assessment of Faculty Usage of YouTube as a Teaching Resource. The Internet Journal of Allied Health Sciences and Practice. 7(1). diperoleh dari http://ijahsp.nova.edu

Carpenter, S. K., \& Toftness, A.R. 2017. The Effect of Prequestions on Learning from Video Presentations. Journal of Applied Research in Memory and Cognition, 6 (1), 104-109. https://doi.org/10.1016/j.jarmac.2016.07.014

Dimyati, Mudjiono, 2006. Belajar dan Pembelajaran. Jakarta: PT. Rineka Cipta

Djamarah, S.B. dan Zain, Aswan. 2006. Strategi Belajar Mengajar. Jakarta: Rineka Cipta

Furi, U. L., \& Mustaji, Nf. 2017. Pengembangan Media Video Mata Pelajaran Komposisi Foto Digital Bagi Siswa Kelas XI Multimedia di Sekolah Menengah Kejuruan. Jurnal Kwangsan, vol.5 No.2, hal. 91-100. DOI: https://doi.org/10.31800/jtp.kw.v5n2.p91--100

Ischak, Warji. 1987. Program Remedial dalam Proses Belajar Mengajar. Yogyakarta: Liberty

Jossberger, H., Brand-Gruwel, S., van de Wiel, M. W. J., \& Boshuizen, H. 2017. Learning in Workplace Simulations in Vocational Education: a Student Perspective. Vocations and Learning. https://doi.org/10.1007/s12186-0179186-7 
Lestari, S. 2015. Faktor-faktor yang Mempengaruhi Pemanfaatan Teknologi Informasi dan Komunikasi oleh Guru. Jurnal Kwangsan, Vol. 3 No. 2, hal. 121-134. DO: https://doi.org/10.31800/jtp.kw.v3n2.p121--134

Makarao, N. R. 2009. Metode Mengajar dalam Bidang Kesehatan. Bandung: Alfabeta

Maulana, A ., Skartaji, G.T.,\& Artur, R. 2019. Pengembangan Media Video Presentasi Pada Mata Kuliah Hidrologi di Universitas Negeri Jakarta. Jurna Kwangsan, Vol. 7 No. 2. Hal. 170-183 DOI: https://doi.org/10.31800/jtp.kw.v7n2.p170--183

Mukhlis, Abdul (ed), 2000. Penelitian Tindakan Kelas, Makalah Panitia Penulisan Karya Ilmiah untuk Guru-guru se-Kabupaten Tuban.

Mustafa, Z. 2019. Pengaruh Discovery Learning Berbantuan e-Learning dalam Meningkatkan Penguasaan Konsep Siswa tentang Konsentrasi Larutan dan Aplikasinya, Jurnal Kwangsan, Vol. 7 No. 1 hal. 14-29, DOI: https://doi.org/10.31800/jtp.kw.v7n1.p14--29

Ngalim P. 2006. Prinsip-Prinsip dan Teknik Evaluasi Pengajaran, Bandung: Remaja Rosdakarya

Prastiyo, W., Djohar, A., \& Purnawan, P. 2018. Development of Youtube integrated google classroom based e-learning media for the light-weight vehicle engineering vocational high school. Jurnal Pendidikan Vokasi, 8 (1), 53. DOI: https://doi.org/10.21831/jpv. v8i1.17356

Purnomo, Y.W. 2011. Keefektifan Model Penemuan Terbimbing Dan Cooperative Learning Pada Pembelajaran Matematika. Jurnal Pendidikan, vol.41, No.1. journal.uny.ac.id

Pusat Pembinaan dan Pengembangan Bahasa. 1995. Kamus Besar Bahasa Indonesia (KBBI). Jakarta: Balai Pustaka.

Revans, Reg. 1998. Action Learning. New York: Hart Publishing Co.

Ristasa, R.A. 2003. Pedoman Penyususunan Proposal dan Penulisan Laporan Penelitian Tindakan Kelas. Purwokerto: Kementerian Pendidikan dan Kebudayaan Universitas Terbuka

Rivalina, R. 2017. Strategi Pemanfaatan e-learning Dalam Mengatasi Keterbatasan Jumlah Dosen. Jurnal Kwangsan, Vol.5 No. 2, hal. 129-145. DOI : http://dx.doi.org/10.31800/jtp.kw.v5n2.p129--145

Rusman, 2016. Pengembangan Model e-Learning untuk Meningkatkan Hasil Belajar Mahasiswa. Jurnal Kwangsan, Vol. 4 No.1, hal. 1-15. DOI : https://doi.org/10.31800/jtp.kw.v4n1.p1--15

Satriyaningsih, 2009. Efektivitas Metode Pembelajaran Tutor Sebaya untuk Meningkatkan Hasil Belajar Biologi pada Pokok Bahasan Ekosistem pada Siswa Kelas VII SMP Bhinneka Karya Klego Boyolali Tahun Ajaran 2008/2009. Skripsi. Surakarta: Universitas Muhammadiyah Surakarta

Smaldino, S. E., Lowther, D. L., \& Russell, J. D., 2012. Instructional Technology \& Media For Learning (9th ed.). Jakarta: Kencana Prenada Media Group Sudjana, N., 2006. Penilaian Hasil Proses Belajar Mengajar, Remaja Rosda Karya 
Thoma, M., \& Ostendorf, A. 2017. Discourse Analysis as a Tool for Promoting the 'Critical Literate' VET Teacher. Vocations and Learning, 11 (2), 1-19. https://doi.org/10.1007/s12186-017-9188-5

Tohari, H. Mustaji \& Bachtiar S.B, 2019. Pengaruh Penggunaan Youtube Terhadap Motivasi Belajar dan Hasil Belajar Mahasiswa. Jurnal Kwangsan, Vol. 7 No. 1 hal. 1-13. DOI: https://doi.org/10.31800/jtp.kw.v7n1.p1--13

Utomo, S.W., Liana V.W. 2019. Penerapan Strategi Blended Learning untuk Meningkatkan Kemampuan Berpikir Kritis Mahasiswa pada Era Revolusi Industri 4.0. Jurnal Kwangsan Vol 7 No. 1. hal. 30-44. DO: https://doi.org/10.31800/jtp.kw.v7n1.p30--44

Winataputra, U.S. 1999. Pendekatan Pembelajaran Kelas Rangkap. Jakarta: Departemen Pendidikan dan Kebudayaan.

Winataputra, U.S. 2005. Strategi Belajar Mengajar. Jakarta : Depdikbud. 